Отже, у процесі застосування екологічних дидактичних ігор учні закріплюють та поглиблюють знання про природні процеси та явища, виявляють ініціативність, креативність, творчість. Дидактична гра в усіх своїх видах виконує різні функції, але домінує - мотиваційна та виховна, саме 3 цих позицій слід оцінювати ії переваги порівняно 3 іншими методами навчання. Для того, щоб дидактична гра ефективно впливала на формування екологічної культури учнів, необхідно дотримуватись вищеописаних методичних вимог, застосовувати ігри систематично та в певній послідовності. Перспективи подальших досліджень вбачаємо у вивченні питання про методичне забезпечення ігрового навчання різних вікових груп учнів.

\title{
Література
}

1. Алексюк А.М. Загальні методи навчання в школі / А. М. Алексюк. - К. : Академвидав, 2004 352 с. 2. Крисак А. Екологічне виховання молоді / А. Крисак // Біологія. - 2009. - № 16.- С. 44-50. 3. Павелків Р. В. Загальна психологія / Р. В. Павелків. - К.: Кондор, 2009. - 576 с. 4. Пруцакова О. Л. Формування основ екологічної культури учнів 5-8-х класів засобами дидактичної гри: автореф. дис. на здобуття наук. ступеня канд. пед. наук : спец. 13.00.07 «Теорія і методика виховання» / О. Л. Пруцакова. K., 2002. -20 c.

УДК 378.094.016:51

Ольга Чашечникова, Тетяна Панченко

\section{РОЗВИТОК НЕСТАНДАРТНОГО МИСЛЕННЯ ШКОЛЯРІВ ЧЕРЕЗ РОЗВ'ЯЗУВАННЯ ФУНКЦІОНАЛЬНИХ РІВНЯНЬ}

Чашечникова О. С., Панченко Т. І. Розвиток нестандартного мислення школярів через розв'язування функціональних рівнянь.

Стаття присвячена теоретико-методичній проблемі формування та розвитку творчого мислення учнів в умовах диференційованого навчання математики. На основі аналізу розв'язування функціональних рівнянь продемонстровано можливості впливу їх виконання на розвиток нестандартного мислення учнів.

Ключові слова: функціональне рівняння, творче мислення, нестандартне мислення.

Чашечникова О.С., Панченко Т.И. Развитие нестандартного мышления школьников посредствам решения функциональных уравнений.

Статья посвящена теоретико-методической проблеме формирования и развития творческого мышления учащихся в условиях дифференцированного обучения математике. На основе анализа решения функциональных уравнений продемонстрированы возможности влияния их выполнения на развитие нестандартного мышления учащихся.

Ключевые слова: функциональное уравнение, творческое, нестандартное мышление.

Chashechnikova O. S., Panchenko T. I. Development of innovative thinking of students through the solution of functional equations.

The article is devoted to the theoretical and methodological bases for formation and development of the creative thinking in differentiated teaching of mathematics. On the basis of functional equations solution analysis, the possibilities of their performance influence on the development of learners' innovative thinking are demonstrated.

Key words: functional equation, creative thinking, original thinking.

Творчість у навчанні математики як обов'язковий компонент передбачає оперування якісною інтелектуальною базою із предмета. Інтелектуальною базою називаємо систему знань та умінь учня (студента) з математики та його досвід іiї використання.

Збагачення інтелектуальної бази з математики, ії вдосконалення не зменшує прагнення людини до пізнання, а стає стимулом до творчості. Тому необхідно максимально використовувати можливості навчання математики для розвитку творчої особистості школярів (студентів) незалежно від обраного ними профілю навчання (майбутньої спеціальності).

Досліджуючи проблеми розвитку творчого мислення учнів в умовах профільного навчання математики [6; 7], ми обгрунтували, що розвинене творче мислення учнів сприяє підвищенню 
успішності навчання математики, натомість формування якісної системи знань і вмінь із математики має бути підпорядковане меті формування та розвитку творчого мислення школярів. У контексті дослідження необхідно доповнити відомі системи принципів навчання математики принципом установки учня (студента) на надзавдання та принципом максимальної опори на наявні надбання учнів (студентів) у інтелектуальній і творчій сферах.

На наш погляд, навчально-пізнавальна діяльність з математики, спрямована на розвиток творчої особистості учня, насамперед має формувати готовність до творчості, яку ми розуміємо як достатньо високий рівень сформованості інтелектуальної бази з предмета, комплексу відповідних здібностей (як загальних, так і спеціальних), сформованість якостей особистості, які сприяють творчій діяльності.

3 метою вияву в учня (студента) задатків творчого мислення в ході реального навчального процесу необхідно враховувати щонайменший зовнішній вияв характеристик творчого мислення учнів. Отже, вчитель (викладач) математики має знати, як побачити прояви творчого мислення школяра (студента) навіть у процесі так званої «звичайної» навчально-пізнавальної діяльності у процесі навчання математики, як скористатися можливостями, що «надає» програмний навчальний матеріал з предмету для розвитку творчого мислення. Нами визначені характеристики творчого мислення, що можна діагностувати та розвивати в процесі навчання математики [6; 7], які характеризують відкритість та спроможність особи до творчості; діапазон творчості; специфіку проходження творчого процесу; результативність творчої діяльності; наявність у суб'єкта рушійних сил творчості.

Зупинимося на такій рисі творчої особистості як нестандартне мислення. Уточнюємо наявні визначення нестандартного мислення: відкритість до незвичних ідей, здатність їх породжувати; відхилення від традиційних схем мислення; спроможність розглядати різні аспекти нової інформації, враховуючи різноманітні нюанси; здатність та схильність до самостійного знаходження проблем, що потребують розв'язання [6; 7]. Нестандартність мислення людини виражається у виявленні оперативності, гнучкості, оригінальності, інтегративності мислення; уяві, фантазії. Навчання математики є потужним засобом розвитку нестандартного мислення учнів (студентів).

Mета статті: продемонструвати можливості розвитку нестандартного мислення учнів у ході розв'язування функціональних рівнянь.

Виражається нестандартність мислення у прояві оперативності, гнучкості, орисінальності, інтегративності мислення; уяві, фантазії. За дослідженнями психологів, розв'язування завдань на розвиток критичного мислення заважає розвитку творчого мислення, і навпаки. Однак ефективність творчої діяльності (навчально-пізнавальної діяльності) з математики на різних ії етапах неможлива без задіяності і творчого, і критичного мислення. Наші дослідження показали, що дійти до певного паритету можна, якщо посилити спрямованість на розвиток оперативності мислення, в якому інтегровані якості й творчого, й критичного мислення.

Під оперативністю мислення розуміємо здатність швидко орієнтуватися у змінених і нових умовах; уміння легко відтворювати та використовувати значну базу математичних знань і вмінь, відбираючи з них ті, використання яких сприяє більш раціональній та продуктивній роботі, за необхідності - адаптуючи, пристосовуючи до наявних умов; різноманітність виникнення ідей, асоціацій, зв'язків. Визначаємо оперативність мислення у процесі навчальнопізнавальної діяльності з математики за швидкістю і легкістю оперування наявними знаннями i уміннями з предмету у конкретній ситуації.

Гнучкість мислення визначаємо як легкість переходу від одного поняття (або способу роботи) до іншого; легкість «переключення»; спроможність відмовлятися від неефективних шляхів розв'язування, відкидати відомості, що не $є$ важливими у даному конкретному випадку; здатність «переставляти» акценти. Визначається за швидкістю переходу від одного об'єкту (способу розв'язування, властивості) до іншого.

У контексті нашого дослідження оригінальність - незвичність підходів до розв'язування завдань, нешаблонність мислення, відхилення від прийнятих стандартів; уміння звільнитися від стереотипів, шаблонів. Визначається за ступенем відхилення запропонованої ідеї, підходу від звичного.

Інтегративність мислення визначається за здатністю створювати асоціації у поєднанні понять з різних (іноді достатньо віддалених) галузей та оперативно користуватися ними. 
Завдяки уяві та фантазії створюються можливості полегшення виконання завдання через його трансформацію. Визначаються за здатністю створювати в уяві конструкції з відомих об'єктів, видозмінені об'єкти, нові об'єкти.

Розв'язування функціональних рівнянь дозволяе школярам (студентам) проявити i розвинути оперативність, гнучкість, оригінальність, інтегративність мислення, уяву. Завдання щодо розв'язування функціональних рівнянь стали фактично обов'язковим елементом математичних олімпіад різних рівнів, як вітчизняних, так і зарубіжних $[1 ; 2 ; 3 ; 4]$. Специфіка роботи над такими завданнями полягає в тому, що представлені вони незвично, хоча, з одного боку, начебто, для розв'язування лише необхідно знати основні поняття так званої «шкільної математики», але з іншого, - необхідно застосовувати їх обмірковано, нестандартно. Отже, розвивається оперативність, гнучкість, оригінальність, інтегративність мислення.

3-поміж способів розв'язування функціональних рівнянь: спосіб невизначених коефіцієнтів, спосіб підстановки; застосування поняття групи; застосування елементів математичного аналізу (зокрема, метод граничного переходу) та інші [1-4]. Детальніше зупинимося на застосуванні способу підстановок. Сутність: припускаємо, що розглядуване рівняння має розв'язок; застосовуємо до змінних, що входять у рівняння, деякі підстановки; дістаємо систему рівнянь таку, що одним із невідомих $\epsilon$ шукана функція; після розв'язування системи безпосередньою перевіркою переконуємося, чи знайдена функція задовольняє умовам задачі.

Найбільш складно для більшості учнів на перших етапах вибрати саме ту підстановку, використання якої є доцільним у конкретному випадку. 3 одного боку, легкість процесу вибору свідчить про те, що у школяра розвинене нестандартне мислення, 3 іншого, - процес пошуку сприяє розвитку нестандартності мислення.

Завдання 1. Знайдіть всі функції $f: R \rightarrow R$, які задовольняють рівнянню $f(x)+2 f(-x)=x+1$.

\section{Розв'язання}

Учень має побачити, що доцільно скористатись підстановкою $x=-x$.

Маємо $f(-x)+2 f(x)=-x+1$.

Необхідно скласти та розв'язати систему:

$\left\{\begin{array}{l}f(x)+2 f(-x)=x+1 \\ f(-x)+2 f(x)=-x+1\end{array}\right.$
$-\mathbf{3} f(x)=\mathbf{3} x-\mathbf{1}, f(x)=\frac{-\mathbf{3} x+\mathbf{1}}{\mathbf{3}}$

Перевірка:

$f(x)=\frac{-3 x+1}{3}$

$+$

$f(x)+2 f(-x)=\frac{3 x+3}{3}=x+1$

Bidnoвidb: $f(x)=\frac{-\mathbf{3} x+\mathbf{1}}{\mathbf{3}}$.

Отже, вищенаведений приклад розв'язування функціонального рівняння демонструє спрацьовування оперативності мислення.

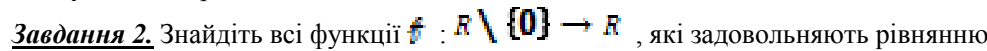

$$
f(x)-3 f\left(\frac{1}{x}\right)=x+\frac{1}{x}
$$

Розв'язання
У даному випадку обираємо підстановку
$x=\frac{1}{x}$.

Маємо.

Розв'яжемо систему: 
$\left\{\begin{array}{l}f(x)-3 f\left(\frac{1}{x}\right)=x+\frac{1}{x} \\ f\left(\frac{1}{x}\right)-3 f(x)=\frac{1}{x}+x\end{array}\right.$

$-8 f(x)=\frac{4}{x}+4 x, f(x)=-\frac{1}{2 x}-\frac{x}{2}$.

Перевірка: $f(x)=-\frac{1}{2 x}-\frac{x}{2},-3 f\left(\frac{1}{x}\right)=-3\left(-\frac{1}{2 x}-\frac{x}{2}\right)$

$f(x)-3 f\left(\frac{1}{x}\right)=-\frac{1}{2 x}-\frac{x}{2}+\frac{3 x}{2}+\frac{3}{2 x}=$

Biдповідb: $^{f}(x)=-\frac{1}{2 x}-\frac{x}{2}$.

Завдання 3. Знайдіть всі функції $f: R \rightarrow R$, які задовольняють рівнянню $f(x y)=y^{2012} f(x)$.

\section{Розв'язання}

Необхідно «спростити» умову. Це можливо, якщо $x=1$.

Маємо $f(y)=y^{2012} f(1) . f(1)=a$, тоді

$f(y)=a \cdot y^{2012}, a=$ const . Значить, $f(x)=a \cdot x^{2012}$.

Перевірка:, $y^{2012} f(x)=y^{2012} \cdot a \cdot x^{2012}$.

Bidnoвidb: $f(x)=a \cdot y^{2012}, a=$ const .

Після виконання даного завдання можна запропонувати таке, у процесі розв'язування якого доцільно скористатися «відкритим» учнями підходом.

Завдання 4. Знайдіть всі функції $f: R \rightarrow R$, які задовольняють рівнянню $f(x+y)=f(x)+y$.

Підстановка $x=1 . f(x)=x+a, a=$ const .

Завдання 5. Знайти $f(2)$, якщо для будь-якого $x \neq 0$ виконується рівність $f(x)+3 f\left(\frac{1}{x}\right)=x^{2}$

Маємо

Розв'язання

Система:

$$
\begin{aligned}
& \left\{\begin{array}{l}
f(x)+3 f\left(\frac{1}{x}\right)=x^{2}, \\
f\left(\frac{1}{x}\right)+3 f(x)=\frac{1}{x^{2}}, \quad-3
\end{array}\right. \\
& -8 f(x)=\frac{-3}{x^{2}}+x^{2}, f(x)=\frac{3}{8 x^{2}}-\frac{x^{2}}{8} .
\end{aligned}
$$

Перевірка:

$$
\begin{aligned}
& f(x)=\frac{3}{8 x^{2}}-\frac{x^{2}}{8} \\
& 3^{f(x)}=\frac{9 x^{2}}{8}-\frac{3}{8 x^{2}} \\
& f(x)+3 f\left(\frac{1}{x}\right)=x^{2} \\
& f(x)=\frac{3}{8 x^{2}}-\frac{x^{2}}{8}
\end{aligned}
$$


$f(2)=\frac{3}{32}-\frac{1}{2}=-\frac{13}{32}$.

Bidnoвidb:

Завдання 6. Знайдіть всі функції $f: R \rightarrow R$, які задовольняють рівнянню $f\left(x^{2}+y\right)=f(x)+f\left(y^{2}\right)$ для будь-яких $x$ і $y$.

Розв'язання

Дуже важливо, щоб учні зрозуміли: якщо йдеться про будь-які значення $x$ і $y$, то можна обрати $x=y=\mathbf{0}$, і це значно спрощує виконання.

$f(0)=f(0)+f(0)=2 f(0)$, тому.

Якщо лише $y=0$, то $f\left(x^{2}\right)=f(x)+f(0)=f(x)$. Звідки: $f\left(x^{2}\right)=f(x)$

Виходячи з того, що $f(\mathbf{0})=\mathbf{0}$, скористаємось тим, що

$\left(x^{2}+y\right)=0$ за умовою $y=-x^{2}$.

Скористаємось підстановкою $y=-x^{2}$ :

$f(0)=f(x)+f\left(x^{4}\right)==f(x)+f(x)=2 f(x)$.

Зауваження. Особливу складність для учнів становить перехід

$f(x)+f\left(\left[(x]^{2}\right)^{2}\right)=f(x)+f\left(x^{2}\right)$. Але достатньо ввести нову змінну $t=$.

отже, $f(x)=\mathbf{0}$

Перевірка: $f\left(x^{2}+y\right)=0, f(x)+f\left(y^{2}\right)=0$.

Biдnовiдb:

Розв'язування функціональних рівнянь учнями не лише вимагає від них спроможності використовувати нестандартні підходи, але й розвиває їхнє нестандартне мислення.

Важливим питанням є готовність майбутніх учителів математики до навчання школярів розв'язувати функціональні рівняння як з метою подальшої підготовки учнів до участі в математичних олімпіадах, конкурсах, турнірах різних рівнів, так і з розвивальною метою спрямованістю на формування та розвиток нестандартного мислення школярів. Більшість сучасних студентів фізико-математичних факультетів педагогічних університетів не $\epsilon$ випускниками класів із поглибленим вивченням математики, і тому часто вони вперше ознайомлюються з поняттям «функціональне рівняння» саме у процесі навчання у вищому навчальному закладі. Отже, необхідно приділяти належну увагу у процесі підготовки майбутніх учителів математики методам розв'язування функціональних рівнянь під час проведення спецкурсів з елементарної математики.

Література

1. Вороний О. М. Готуємось до олімпіад з математики / О. М. Вороний. - Х. : Основа, 2008. 255 с. 2. Зарубежные математические олимпиады / Конягин С. В., Тоноян Г.А., Шарыгин И.Ф. и др.; под ред. И. Н. Сергеева. - М.: Наука. Гл. ред. физ-мат. лит., 1987. - 416 с. 3. Лихтарников Л. М. Элементарное введение в функциональные уравнения / Л. М. Лихтарников. - СПб.: Лань, 1997. - 160 с. 4. Обласні математичні олімпіади / Конет І. М., Паньков В., Радченко В. М., Теплинський Ю. В. Кам'янець-Подільський: Абетка, 2000. - 304 с. 5. Психологическая диагностика детей и подростков. [учеб. пос. для студ.] М. К. Акимова, Г. А. Берулава, Е. М. Борисова, и др. / под ред. К. М. Гуревича и Е. М. Борисовой. - М. : Межд. пер. академия, 1995. - 360 с. 6. Чашечникова О. С. Система компонентів творчого мислення, що можуть діагностуватися в процесі навчання математики / О. С. Чашечникова // Дидактика математики : проблеми і дослідження : міжнародний збірник наукових робіт. - Вип. 22. - Донецьк : Фірма ТЕАН, 2004. - С. 81-87. 7. Чашечникова О. С. Теоретико-методичні основи формування i розвитку творчого мислення учнів в умовах диференційованого навчання математики / О. С. Чашечникова : дис. ... докт. пед. наук: спец. 13.00.02 «Теорія та методика навчання (математика)». - Сум ДПУ ім. А. С. Макаренка. - Суми, 2011. - 558 с. 